\title{
Characterization of porcine ENO3: genomic and cDNA structure, polymorphism and expression
}

\author{
Jian $\mathrm{Wu}^{1 * *}$, Donghai Zhou ${ }^{2 * *}$, Changyan $\mathrm{DeNG}^{3 *}$, Xiaoxiong $\mathrm{Wu}^{1}$, \\ Liangqi LoNG ${ }^{1}$, Yuanzhu XIONG ${ }^{3}$ \\ ${ }^{1}$ Department of Basic Veterinary Medicine, School of Animal Sciences and School \\ of Veterinary Medicine, Huazhong Agricultural University, Wuhan 430070, P. R. China \\ ${ }^{2}$ College of Veterinary Medicine, Huazhong Agricultural University, \\ Wuhan 430070, P. R. China \\ ${ }^{3}$ Key Laboratory of Swine Genetics and Breeding, Ministry of Agriculture, \\ College of Animal Science and Technology, Huazhong Agricultural University, \\ Wuhan 430070, P. R. China
}

(Received 1st December 2007; accepted 4 March 2008)

\begin{abstract}
In this study, a full-length cDNA of the porcine ENO3 gene encoding a 434 amino acid protein was isolated. It contains 12 exons over approximately $5.4 \mathrm{~kb}$. Differential splicing in the $5^{\prime}$-untranslated sequence generates two forms of mRNA that differ from each other in the presence or absence of a 142-nucleotide fragment. Expression analysis showed that transcript 1 of ENO3 is highly expressed in liver and lung, while transcript 2 is highly expressed in skeletal muscle and heart. We provide the first evidence that in skeletal muscle expression of ENO3 is different between Yorkshire and Meishan pig breeds. Furthermore, real-time polymerase chain reaction revealed that, in Yorkshire pigs, skeletal muscle expression of transcript 1 is identical at postnatal day- 1 and at other stages while that of transcript 2 is higher. Moreover, expression of transcript 1 is lower in skeletal muscle and all other tissue samples than that of transcript 2, with the exception of liver and kidney. Statistical analysis showed the existence of a polymorphism in the ENO3 gene between Chinese indigenous and introduced commercial western pig breeds and that it associated with fat percentage, average backfat thickness, meat marbling and intramuscular fat in two different populations.
\end{abstract}

pig / ENO3 / polymorphism

\footnotetext{
*Corresponding author: guanjian830@126.com

${ }^{* *}$ These two authors contributed equally to this work.
} 


\section{INTRODUCTION}

Enolase is a glycolytic enzyme (2-phospho-D-glycerate hydrolyase) that catalyses the interconversion of 2-phosphoglycerate to phosphoenolpyruvate in the glycolytic pathway. In higher vertebrates, the active enolase enzyme is a dimer composed of three different subunits, alpha, beta and gamma, encoded by separate genes. The expression of these genes is regulated in a tissue-specific and development-specific manner: ENO1 (alpha enolase) is expressed in many tissues while $E N O 2$ (gamma enolase) is expressed only in cells of the nervous system and $E N O 3$ (beta enolase) is localized to muscle tissue [2]. A switch from alpha enolase to beta enolase occurs in muscle tissue during development in rodents [14]. During ontogenesis, striated muscle differentiation is accompanied by an increase in beta-enolase expression and by a decrease in the expression of the alpha isoform [6,11]. It has been shown that ENO3 is expressed in proliferating adult myoblasts as well as in differentiated myotubes and that it is one of the earliest markers of myogenic differentiation in man [6]. In adult human muscle, over $90 \%$ of the enolase activity is accounted for by the beta-enolase subunit encoded by the $E N O 3$ gene. Mutations in this gene can be associated with metabolic myopathies that may result from a decreased stability of the enzyme [4].

Feo et al. [5] have mapped ENO3 to human chromosome 17pter-p11 by analysis of rodent-human somatic cell hybrids and transfectant cell lines carrying different portions of human chromosome 17. In pig, the ENO3 gene has been assigned to pig chromosome SSC12 [10]. However, data on the characterization of the porcine ENO3 gene are still scarce. In the present study, we describe the cDNA cloning and the expression analysis of two transcripts of the porcine ENO3 gene. In addition, the genomic structure, polymorphism and association analysis of this gene were studied.

\section{MATERIALS AND METHODS}

\subsection{Isolation of porcine $E N O 3$ gene}

Initially, pig ESTs were identified using the cDNA sequence of human ENO3 (NM_053013) and mouse Eno3 (NM_007933) by running a BLASTN search against the GenBank 'EST-others' databases. These ESTs were retrieved and then assembled into one contig. From this contig and the human sequence, primers (EN-1F, EN-1R) and (EN-2F, EN-2R) were designed using Primer 5.0 software (http://www.premierbiosoft.com). These primers yielded two overlapping polymerase chain reaction (PCR) products. The purified PCR products were cloned into the pGEM-T vector (TaKaRa, Dalian, China) and sequenced using standard M13 primers. 
The cDNA sequence of pig ENO3 gene was compared with the human and mouse orthologous mRNAs and their genomic sequences to predict the genomic organization of the pig gene, which was confirmed by PCR amplification and sequencing. Four primer pairs were designed to amplify the genomic fragments including all introns (Tab. I). Three genomic DNA mixture pools from three pig breeds (Yorkshire, Landrace and Meishan) were used. DNA sequences were compiled using the DNA star software (Madison, WI, USA). Sequence data of ENO3 in different pig breeds were compared by BLAST (http://www.ncbi. nlm.nih.gov).

\subsection{RACE-PCR and identification of transcripts}

To amplify the $5^{\prime}$ end of the ENO3 gene, cDNA was generated by the SMART PCR cDNA Synthesis Kit (Clontech, Mountain View, CA, USA) using as template total RNA isolated from the longissimus dorsi of Yorkshire pig and the 5'- rapid amplification of cDNA ends (RACE) primer complementary to exon 2 and the SMART II oligonucleotide primer (SMART 5' in Tab. I).

Possible alternative splice donor sites in the $5^{\prime}$ end were predicted by comparing the genomic DNA sequence of the pig ENO3 gene with its cDNA sequence and by using information available in man and mouse on the two betaenolase mRNA forms. Based on the pig genomic sequence, the primer pair (EN-3F, EN-3R) was designed to amplify the other transcript from the cDNA of Yorkshire pigs' longissimus dorsi. These primers bind to the $5^{\prime}$ end of intron 1 and the exon 4-exon 5 region, respectively. The RNA secondary structures in 5'-untranslated regions (UTR) of the two transcripts of the ENO3 gene were predicted using RNA secondary structure prediction software (http://www.genebee.msu.su/services/rna2_reduced.html).

\subsection{Analysis of ENO3 expression levels}

Total RNA was extracted using TRIzoL reagent (Invitrogen, Carlsbad, CA, USA) from the longissimus dorsi of Yorkshire pigs at postnatal day-1, day-60 and day-120 and Meishan pigs at postnatal day-60, respectively. We used three animals of each breed and at each stage, which were reared in same conditions and slaughtered at the same slaughterhouse on the same day. RNA samples were also isolated from other tissues of Yorkshire breed at day-120 i.e. fat, heart, liver, spleen, kidney, lung, stomach, small intestine and uterus. Reverse transcriptase PCR was carried out using M-MLV Reverse Transcriptase (Promega, USA).

For amplification, two transcript primer pairs (trans-1F, trans-1R and trans-2F, trans-2R) were designed using cDNA sequences as templates and Primer Express 
Table I. Primers used in this study.

\begin{tabular}{|c|c|c|c|c|}
\hline Primer name & Sequence $\left(5^{\prime}-3^{\prime}\right)$ & $\begin{array}{l}\text { Binding } \\
\text { region }\end{array}$ & Annealing temperature $\left({ }^{\circ} \mathrm{C}\right)$ & Size (bp) \\
\hline $5^{\prime}$-RACE & GCAGGTCCACCTCCACTGT & Exon 2 & 59 & 155 \\
\hline SMART $5^{\prime}$ & GCAGTGGTATCAACGCAGAGTACGC & & & \\
\hline EN-1F & AGCTGCCACCTCTACTCC & Exon 1 & 55 & 218 \\
\hline EN-1R & CCAGGTAGCGAGATTTGTC & Exon 3 & & \\
\hline $\mathrm{EN}-2 \mathrm{~F}$ & CTTCCACGGGTATCTATGA & Exon 3 & 55 & 1269 \\
\hline EN-2R & GTTGGCACCAGTGTTTATT & Exon 12 & & \\
\hline $\mathrm{EN}-3 \mathrm{~F}$ & CTGATGACTCTTCCAGCCTC & Intron 1 & 58 & 295 \\
\hline EN-3R & ACACTTAGTTTCTTTTCCAGCA & Exon $4 \sim$ exon 5 & & \\
\hline trans- $1 \mathrm{~F}$ & GTTGGAGCAAGCAGGACG & $142 \mathrm{bp}$ insert sequence & 60 & 201 \\
\hline trans-1R & TGCCCAGGTAGCGAGATT & Exon 3 & & \\
\hline trans- $2 \mathrm{~F}$ & GCGAAGACATCCCAGCCAT & Exon $1 \sim$ exon 2 & 60 & 194 \\
\hline trans-2R & GCCCAGGTAGCGAGATTTG & Exon 3 & & \\
\hline GAPDH-F & GAAGGTCGGAGTGAACGGAT & Exon 2 & 60 & 251 \\
\hline GAPDH-R & CTCATTTGATGTTGGCGGG & Exon 4 & & \\
\hline Genomic $1-2 \mathrm{~F}$ & AGCTGCCACCTCTACTCC & Exon 1 & 55 & 1191 \\
\hline Genomic $1-2 \mathrm{R}$ & GTCCCGTCCTCTTTCCTA & Intron 3 & & \\
\hline Genomic 3-6F & CCGATTCCGAGCTGCTGT & Exon 3 & 62 & 2438 \\
\hline Genomic 3-6R & CATTGGTGGCGTCCTTCC & Exon 7 & & \\
\hline Genomic $7-8 \mathrm{~F}$ & ATCAAGGGCAAATACGGG & Exon 7 & 54 & 820 \\
\hline Genomic 7-8R & GAGGTCCAGGTCTTCCAGT & Exon 9 & & \\
\hline Genomic $8-11 \mathrm{~F}$ & GGCATCTGAGTTCTACCGC & Exon 8 & 55 & 1702 \\
\hline Genomic $8-11 \mathrm{R}$ & GGCACCAGTGTTTATTTCG & Exon 12 & & \\
\hline SNP-F & AGATTCTGCTTCGTCCCA & Intron 9 & 55 & 687 \\
\hline SNP-R & GGCTTCCACCTTCTCACT & Exon 12 & & \\
\hline
\end{tabular}


software (Tab. I). Quantitative PCRs were performed in $25 \mu \mathrm{L}$ volumes containing $12.5 \mu \mathrm{L}$ of $2 \times$ SYBR Green Real-time PCR Master Mix (TOYOBO, Japan), $1 \mu \mathrm{L}$ cDNA and $0.3 \mu \mathrm{M}$ (final concentration) of each primer. PCR was run in the Applied Biosystems 7500 Real-Time PCR System. Fluorescent signals were continually monitored at the end of each PCR cycle consisting of $1 \mathrm{~min}$ at $95{ }^{\circ} \mathrm{C}$ for the initial denaturing step, $15 \mathrm{~s}$ at $95{ }^{\circ} \mathrm{C}, 15 \mathrm{~s}$ at $60^{\circ} \mathrm{C}$ and $45 \mathrm{~s}$ at $72{ }^{\circ} \mathrm{C}$ for a total of 40 cycles. The relative expression levels of the gene were analysed using the Comparative $\mathrm{Ct}$ method, in which glyceraldehyde-3-phosphate-dehydrogenase $(G A P D H)$ was used as an internal control, to correct for the differences in the mRNA quantities. For amplification of $G A P D H$, a specific primer pair (GAPDH-F and GAPDH-R, see Tab. I) was used producing a $251 \mathrm{bp}$ fragment under the same PCR conditions as above. $t$-test was performed to conclude on the significance of the observed differences.

\subsection{Detection of polymorphisms and association analysis}

Based on the BLAST results of intron 9 sequences in Yorkshire, Landrace and Meishan, primer pair (SNP-F, SNP-R) was used to detect PCR-StuI- restriction fragment length polymorphism (RFLP). PCR was performed in $20 \mu \mathrm{L}$ reaction mix containing: $25 \mathrm{ng}$ of genomic DNA pool, $150 \mu \mathrm{M}$ dNTP, $0.25 \mu \mathrm{mol}$ of each PCR primer, $1 \mathrm{U}$ Taq DNA polymerase supplied by the manufacturer. PCRs were run as follows: an initial step at $94{ }^{\circ} \mathrm{C}$ for $4 \mathrm{~min}, 35$ cycles at $94{ }^{\circ} \mathrm{C}$ for $40 \mathrm{~s}, 55^{\circ} \mathrm{C}$ for $40 \mathrm{~s}, 72{ }^{\circ} \mathrm{C}$ for $40 \mathrm{~s}$ and a final extension step at $72{ }^{\circ} \mathrm{C}$ for $10 \mathrm{~min}$. For the PCR-RFLP assays, $7.5 \mu \mathrm{L}$ of PCR products was digested with $5 \mathrm{U}$ StuI (TaKaRa) in $1 \mathrm{X}$ digestion buffer with $1 \mathrm{X}$ BSA added in a total volume of $10 \mu \mathrm{L}$. Following the digestion at $37{ }^{\circ} \mathrm{C}$ for $4 \mathrm{~h}$, the products were separated by electrophoresis on a $1.5 \%$ agarose gel in $1 \mathrm{X}$ TAE buffer and stained with $0.5 \mu \mathrm{g} \cdot \mathrm{mL}^{-1}$ ethidium bromide.

Allele frequencies were determined in eight different populations. The StuI PCR-RFLP was genotyped in 132 pigs (34 Yorkshire pigs, 37 Landrace pigs, 35 Landrace $\times$ Yorkshire and 26 Yorkshire $\times$ Landrace pigs) [18] and $140 \mathrm{~F}_{2}$ pigs of a Yorkshire $\times$ Meishan reference family [17]. The association between genotype and production traits was performed with the least square method (GLM procedure, $\mathrm{SAS}^{\circledR}$ version 8.0). The model used to analyse the data was assumed to be:

$$
\begin{array}{ll}
Y_{i j k}=\mu+G_{i}+S_{j}+B_{k}+b_{i j k} X_{i j k}+e_{i j k} & {[18]} \\
Y_{i j k}=\mu+G_{i}+S_{j}+F_{k}+b_{i j k} X_{i j k}+e_{i j k} & {[16]}
\end{array}
$$

where $Y_{i j k}$ is the observation of the trait; $\mu$ is the least square mean; $G_{i}$ is the effect of $i$ th genotype; $S_{j}$ is the effect of $j$ th sex ( $j=1$ for male or 2 for female); 
$B_{k}$ is the effect of $k$ th breed; $F_{k}$ is the effect of $k$ th family; $b_{i j k}$ is the regression coefficient of the slaughter weight and $e_{i j k}$ is the random residual.

\section{RESULTS AND DISCUSSION}

\subsection{Two mRNA forms for the porcine ENO3 gene}

Primer pairs (EN1F, EN1R) and (EN2F, EN2R) amplified two fragments $218 \mathrm{bp}$ and $1269 \mathrm{bp}$ long, respectively, which resulted in a consensus sequence of 1426 bp corresponding to pig ENO3 coding sequence (GenBank Accession No. DQ355513). Using RACE-PCR, we obtained a 155 bp fragment containing all of exon 1 and part of exon 2 . The sequence comparison of this $155 \mathrm{bp}$ fragment with the 1426 bp ENO3 coding sequence produced a full-length consensus sequence of 1437 bp (GenBank Accession No. EU418440), which shares the highest sequence identity with variant 2 of human ENO3 transcript that lacks exon 1 as compared to variant 1 . Aligning pig ENO3 cDNA and genomic sequences with the human $E N O 3$ sequence revealed a possible splice donor site in the $3^{\prime}$ end of exon 1. Primer pair (EN-3F, EN-3R) amplifies a 393 bp cDNA fragment containing $140 \mathrm{bp}$ of intron 1 , exon 2, exon 3 , exon 4 and part of exon 5. Thus, two forms of pig ENO3 mRNA exist that differ by the presence or absence of a 142-nucleotide fragment in the $3^{\prime}$ end of exon 1 . Based on the sequence of the human ENO3 [7], porcine ENO3 transcript 1 containing the 142-nucleotide insert is the long form of ENO3 mRNA i.e. $1579 \mathrm{bp}$ (GenBank Accession No. EU418439) while transcript 2 corresponds to the short form of ENO3 mRNA i.e. 1437 bp (GenBank Accession No. EU418440). Aligning this pig sequence with the human $E N O 3$ and mouse Eno3 cDNA sequences revealed a $54 \mathrm{bp}$ or $196 \mathrm{bp}$ of $5^{\prime}$-untranslated sequence, $1305 \mathrm{bp}$ of coding sequence and 78 bp of $3^{\prime}$-untranslated sequence. The sequence "AATAAA" indicating a putative polyadenylation signal was found in the $78 \mathrm{bp}$ fragment of the $3^{\prime}$ end sequence. The coding region of the porcine ENO3 as determined by alignments shares 90 and $85 \%$ identity with human and mouse cDNAs, respectively. The deduced protein contains 434 amino acids showing $97 \%$ sequence similarity with the human and mouse proteins.

Computer-generated predictions of the most stable leader secondary structure of the two splice forms are illustrated in Figure 1. Introduction of the 142-nucleotide fragment (transcript 1) produced a markedly altered folding pattern, leading to the formation of a very stable stem-loop structure with a predicted free energy $=-42.7 \mathrm{kcal} \cdot \mathrm{mol}^{-1}$. In contrast, the potential structure of the short transcript 2 had a predicted free energy $=-4.8 \mathrm{kcal} \cdot \mathrm{mol}^{-1}$, representing a significantly less stable secondary structure. 


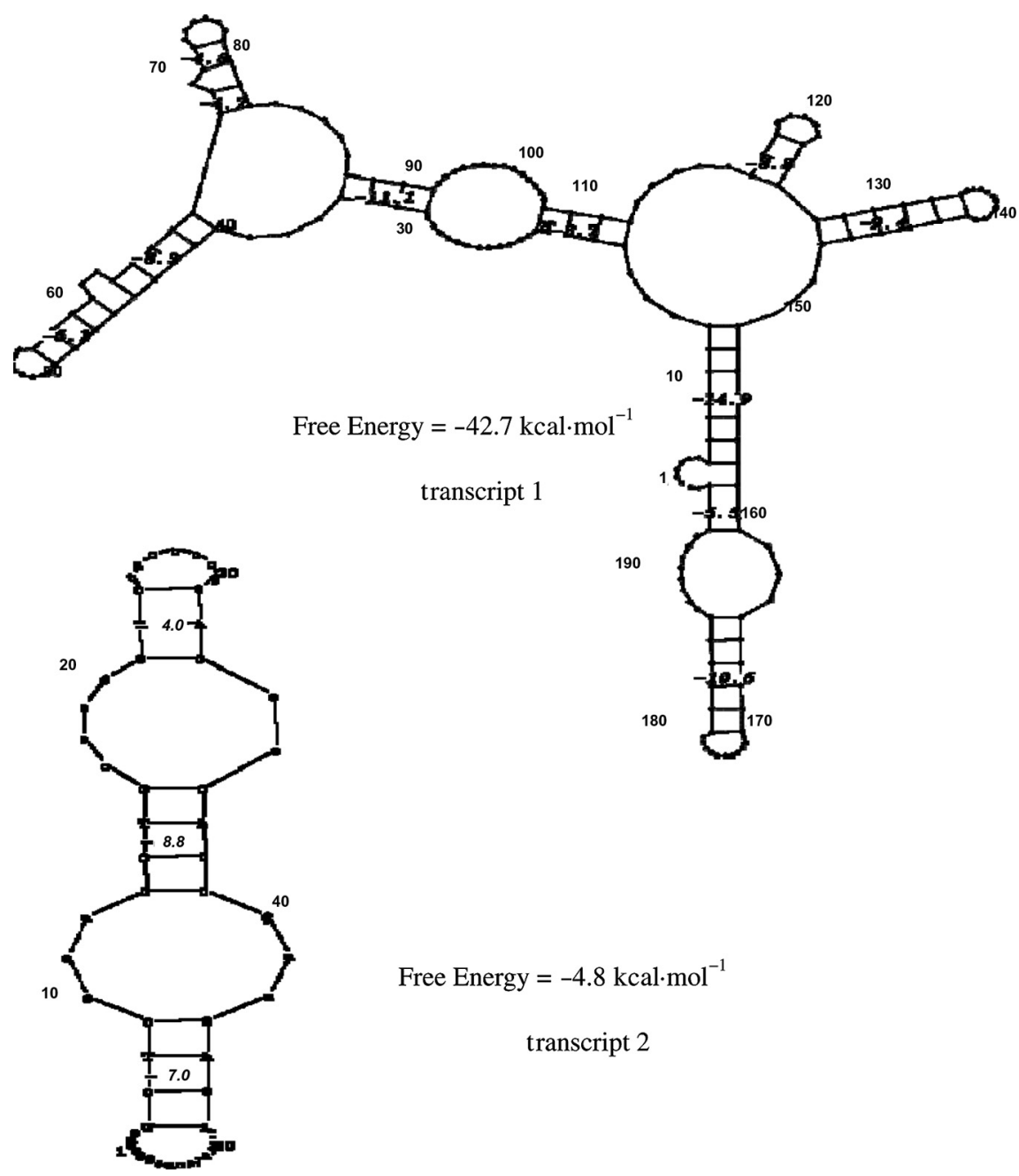

Figure 1. Predicted secondary structure of the 5'-UTR of ENO3 mRNA. The software predicted the most stable stem-loop structure in the $5^{\prime}$-UTR of both transcripts with the smallest free energy method. Overall free energy of formation values is $-42.7 \mathrm{kcal} \cdot \mathrm{mol}^{-1}$ and $-4.8 \mathrm{kcal} \cdot \mathrm{mol}^{-1}$ for the long (transcript 1) and the short (transcript 2) splice forms, respectively.

\subsection{Differential expression of the two transcripts}

Spatial expression analysis of $E N O 3$ showed that the expression level of transcript 1 in muscle, fat, heart, small intestine, stomach and uterus is extremely weak and slightly higher in liver, lung and kidney (Fig. 2A). The level of transcript 1 mRNA is undetectable in spleen (Fig. 2A). Real-time PCR revealed that 
the expression level of transcript 2 was high in skeletal muscle and heart, with medium levels in fat, lung and stomach, with low levels in liver, spleen, kidney, small intestine and uterus (Fig. 2B). Compared to that of transcript 2, the expression level of transcript 1 is very low in all tissues, with the exception of liver and kidney (Fig. 2B).

Expression of ENO3 transcript $1 \mathrm{mRNA}$ showed no variation during the three stages of skeletal muscle development in Yorkshire pigs, while expression of transcript 2 was highest in skeletal muscle at postnatal day- 1 and lower at day- 60 but was upregulated with age (Fig. 3). Compared with that of transcript 2, the expression level of transcript 1 is very low in skeletal muscle (Fig. 3). An expression pattern was also analysed in the skeletal muscle of both Western Yorkshire and Chinese Meishan pigs at day-60. The two transcripts were differentially expressed in the skeletal muscle between Yorkshire and Meishan (Fig. 4). Moreover, the transcript level of pig ENO3 transcript 1 was very low in all the samples of skeletal muscle. The expression level of transcript 2 was higher in the skeletal muscle of Yorkshire than that of Meishan but the expression of transcript 1 showed no difference between both breeds (Fig. 4).

\subsection{Genomic structure of the ENO3 gene}

The resulting overlapping PCR products were assembled into a single contig revealing the complete sequence of pig ENO3 gene (GenBank Accession No. DQ676935). A 5376 bp genomic DNA sequence covering the entire coding region of the porcine $E N O 3$ gene was amplified using four gene-specific primer pairs (Tab. I) and compared with the cDNA sequence to clarify the exon/intron organization. The porcine ENO3 gene is composed of 12 exons and 11 introns (Fig. 5) with the first intron interrupting the $5^{\prime}$-untranslated sequence, just $2 \mathrm{bp}$ upstream of the initiation methionine codon. All splice donor and acceptor sites conform to the typical $5^{\prime}$ GT-AG $3^{\prime}$ rule, with the exception of the donor site of intron 4, which is GC instead of GT. Sizes of ENO3 exons vary between 52 and $223 \mathrm{bp}$ and sizes of the introns vary between 82 and $1155 \mathrm{bp}$ in size (Tab. II). This sequence will be useful to search for SNPs and for association analyses.

\subsection{Detection of the ENO3 polymorphism and association analysis}

By comparing the sequence from these different pig breeds, we detected several SNPs and a T deletion mutation (g.404delT) at position 404 in intron 9 that spans a $S t u I$ restriction site. Primer pair 4 amplifies a 687 bp fragment containing part of intron 9 , exon 10 , intron 10 , exon 11 , intron 11 and part of exon 12 


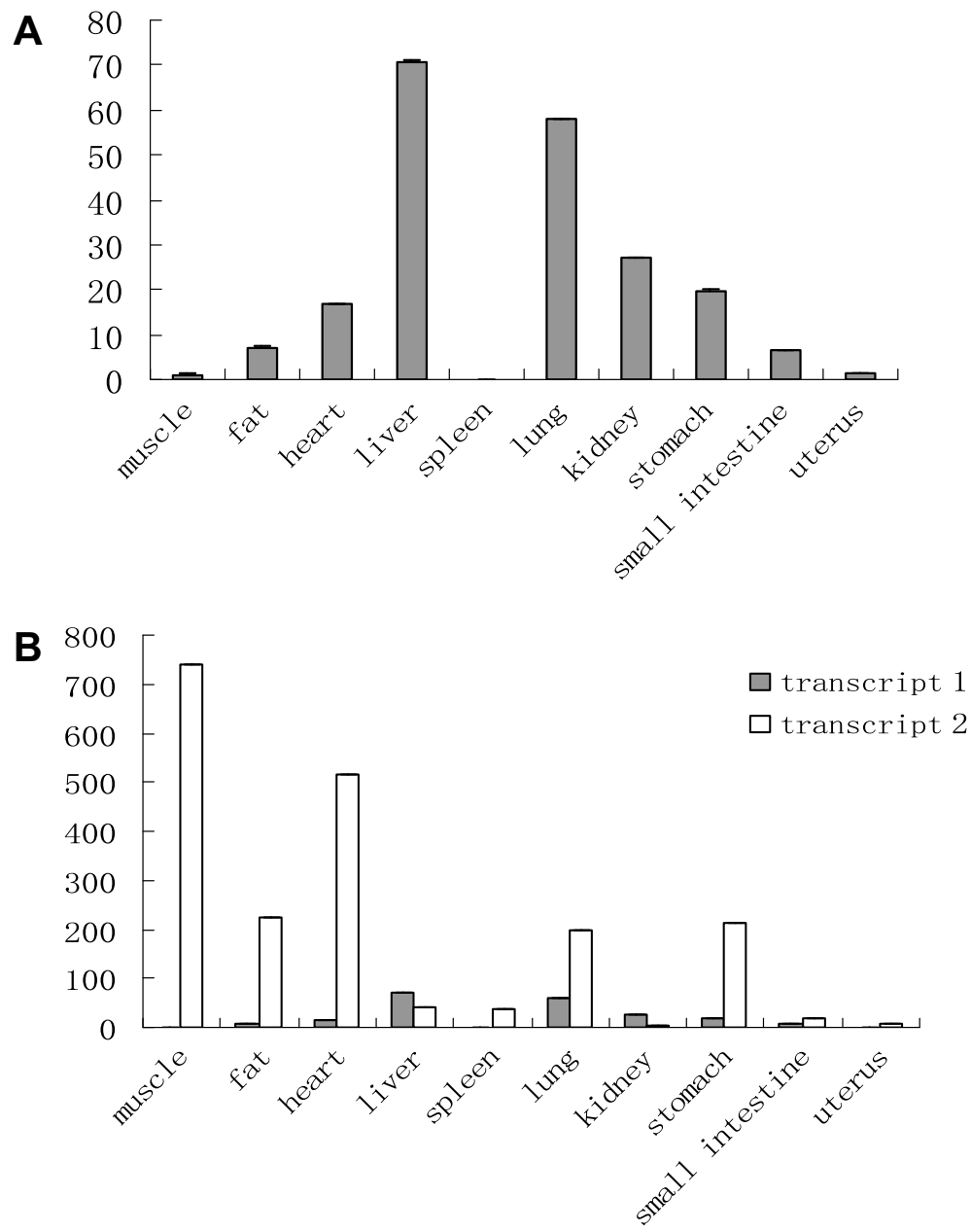

Figure 2. Spatial expression profiles of the two porcine ENO3 transcripts. (A) Expression of ENO3 transcript 1 in different tissues. (B) Relative expression levels of both transcripts. Real-time PCR analysed the expression of ENO3 in different tissues of an adult Yorkshire pig. The relative expression levels of ENO3 mRNA were analysed using the Comparative $\mathrm{Ct}$ method, with $G A P D H$ as the reference gene in each sample. The difference in the levels of expression was significant $(P<0.05)$ by $t$-test analysis.

and was scanned for polymorphism. The $687 \mathrm{bp}$ (allele $A$ ) PCR product was digested into two fragments of $169 \mathrm{bp}$ and $518 \mathrm{bp}$, respectively, the latter corresponding to allele $B$. Allele frequencies for the ENO3 StuI PCR-RFLP were studied in a sample of 244 unrelated pigs, belonging to eight different populations (Tab. III). The allele distribution revealed that in Chinese indigenous 


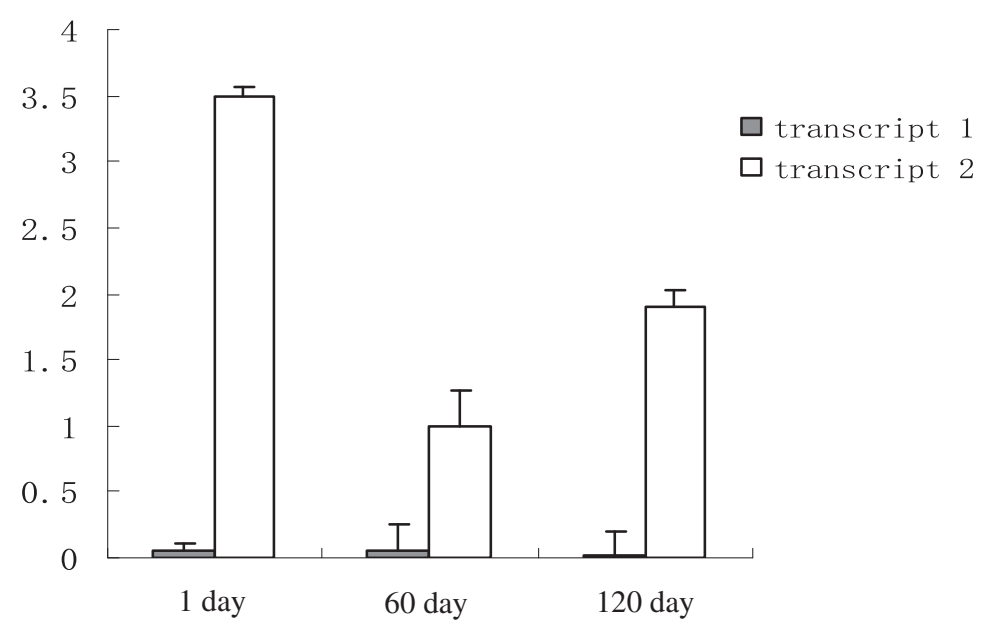

Figure 3. Temporal expression profiles of the two porcine ENO3 transcripts. Relative levels of ENO3 mRNA were calculated using the Comparative $\mathrm{Ct}$ method with $G A P D H$ as the reference gene in each sample. Bars represent the mean $\pm \mathrm{SE}(n=3)$. 1 day, 60 day and 120 day indicate three stages of skeletal muscle development in Yorkshire pigs, postnatal day-1, day-60 and day-120, respectively. For transcript 1, the differences in expression level for the three stages examined were not significant $(P>0.05)$.

breeds, with the exception of the Bamei pigs, allele $A$ was more frequent than in western pig breeds i.e. genotype $B B$ was prevalent in Landrace and Duroc but not in Yorkshire pigs in which allele $A$ was prevalent.

The results of the association analysis between ENO3 genotypes and product traits in two different populations are given in Table IV. Statistically significant associations with fat percentage, average backfat thickness, meat marbling and intramuscular fat were found in $140 \mathrm{~F}_{2}$ Yorkshire $\times$ Meishan pigs. In the other population of 132 pigs composed of 34 Yorkshire pigs, 37 Landrace pigs, 35 Landrace $\times$ Yorkshire and 26 Yorkshire $\times$ Landrace pigs, significant associations with fat percentage, meat marbling and intramuscular fat were also found. No significant conclusion could be drawn for other carcass traits and meat quality traits. Pigs with the $A A$ genotype tended to have more desirable characteristics. Allele $A$ was associated with an increase in meat marbling, intramuscular fat and decrease of fat percentage in the two populations.

\section{DISCUSSION}

In the present study, we report the isolation of pig ENO3 gene and its structural features. The deduced polypeptide shows a high degree of homology with 


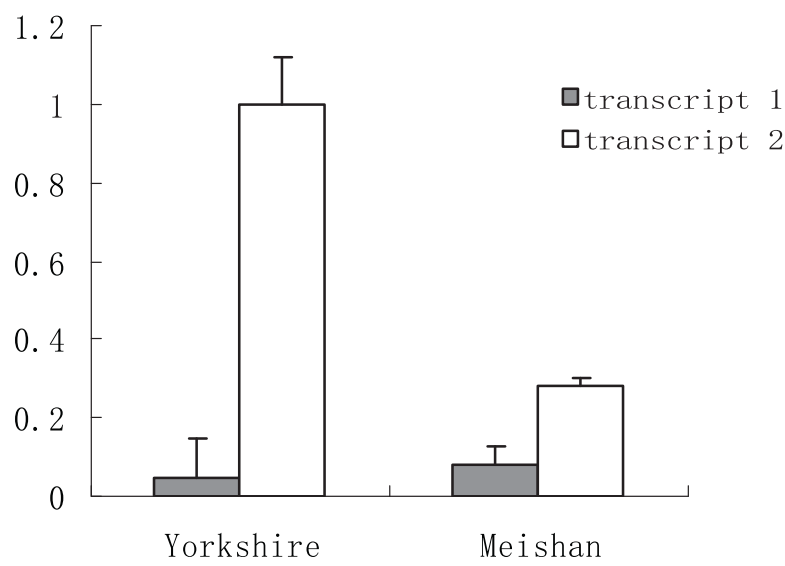

Figure 4. Differential expression analysis of the two porcine ENO3 transcripts in different pig breeds. Real-time PCR analysis of both transcripts in the skeletal muscle of Yorkshire and Meishan pigs at day-60. Relative levels of ENO3 mRNA were calculated using the Comparative $\mathrm{Ct}$ method with $G A P D H$ as the reference gene in each sample. Bars represent the mean $\pm \mathrm{SE}(n=3)$. The differences in the expression levels of transcript 2 between both pig breeds and between both transcripts in each breed were significant $(P<0.05)$ by $t$-test analysis.

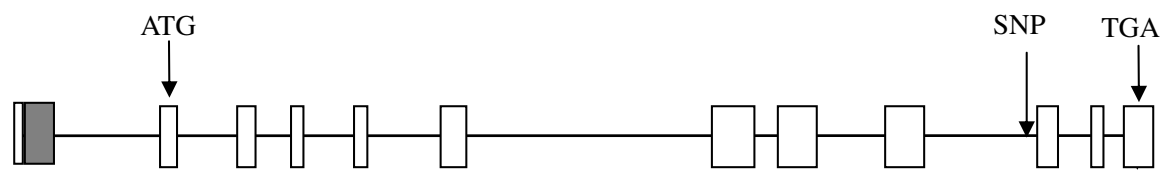

Figure 5. Schematic diagram of the genomic organization of pig ENO3 gene. Boxes correspond to the 12 exons and horizontal lines correspond to the 11 introns. The hatched box in the untranslated exon 1 represents the 142-nucleotide insert present in the long form of ENO3 mRNA (transcript 1).

that of other species. As in man and rat $[13,15]$, porcine ENO3 gene spans a region of about $6 \mathrm{~kb}$ and contains 12 exons. All intron/exon splice donor and acceptor sites conform to the human ENO3 gene. In man, two mRNA forms exist that differ from one another by the presence or absence of a $42 \mathrm{bp}$ fragment due to differential splicing in the leader sequence [7]. This mechanism of alternative splicing, generating two mRNA forms, is also conserved in mouse [12], in which a $110 \mathrm{bp}$ sequence is inserted in the 5'-UTR of the Eno3 gene 
Table II. Genomic structure of the porcine ENO3 gene.

\begin{tabular}{|c|c|c|c|}
\hline Exon & Sequence $\left(5^{\prime}-3^{\prime}\right)$ & Intron & Sequence \\
\hline I (52/194 bp) & CATCCCAGgtctga/GGACGGAGgtactc & $1(612 / 470 \mathrm{bp})$ & cctcttgccetgcagCC ATG GCC \\
\hline II (87 bp) & GGCCAAGGgtaact & $2(270 \mathrm{bp})$ & ttcctcccaccccagGCCGATTC \\
\hline III (96 bp) & GGGCAAAGgtgaga & $3(168 \mathrm{bp})$ & cttcggcetctctagGGGTCCTG \\
\hline IV (59 bp) & TGGAAAAGgcaagt & $4(185 \mathrm{bp})$ & aacctgeccttccagAAACTAAG \\
\hline $\mathrm{V}(70 \mathrm{bp})$ & AAATAAGTgtgagt & $5(397 \mathrm{bp})$ & acttgettcctccagCCAAGTTT \\
\hline VI (134 bp) & CCGTCCCTgtgagt & $6(1155 \mathrm{bp})$ & gtctccecttctcagGCCTTCAA \\
\hline VII (223 bp) & CAATGAAGgtcagt & $7(91 \mathrm{bp})$ & cttgececetcccagCCCTGGAG \\
\hline VIII (198 bp) & CTATCCTGgtgagc & $8(397 \mathrm{bp})$ & gcccettcccaccagTGGTCTCC \\
\hline IX (202 bp) & ATCCAGGCgtgagt & 9 (426 bp) & gtcctctcccccagCTGCAAAC \\
\hline $\mathrm{X}(109 \mathrm{bp})$ & CGGGACAGgtacgc & $10(159 \mathrm{bp})$ & cttttccetcctcagATCAAGAC \\
\hline XI (59 bp) & CTCATGAGgtacag & $11(82 \mathrm{bp})$ & gactttgctttccagGATTGAGG \\
\hline XII (148 bp) & \multicolumn{3}{|c|}{$\begin{array}{l}\text { CCAAGTGAGAAGGTGGAAGCCCCTGGAGCCCGCAGGGCAGATCTGGGCCTTCAAGCCCTTCCCCCGA } \\
\text { AATAAACACTGGTGCCAAC }\end{array}$} \\
\hline
\end{tabular}

Uppercase letters correspond to exon sequences and lowercase letters to intron sequences. Exon and intron sizes are indicated in brackets. Putative $3^{\prime}$-mRNA processing signals are underlined. The initiation codon ATG and stop codon TGA are inserted in a box. 
Table III. Genotype and allele frequencies of pig ENO3 gene in eight pig breeds.

\begin{tabular}{lccccccc}
\hline Breeds & Number & \multicolumn{3}{c}{ Genotype } & & \multicolumn{2}{c}{ Allele frequencies } \\
\cline { 3 - 5 } & & $A A$ & $A B$ & $B B$ & & $A$ & $B$ \\
\hline Yorkshire & 38 & 20 & 15 & 3 & & 0.724 & 0.276 \\
Landrace & 39 & 3 & 22 & 14 & & 0.359 & 0.641 \\
Duroc & 22 & 0 & 3 & 19 & & 0.068 & 0.932 \\
Meishan & 42 & 25 & 15 & 2 & & 0.774 & 0.226 \\
Huainan & 15 & 7 & 8 & 0 & & 0.733 & 0.267 \\
Qingping & 45 & 26 & 19 & 0 & & 0.789 & 0.211 \\
Erhualian & 31 & 28 & 3 & 0 & & 0.952 & 0.048 \\
Bamei & 12 & 3 & 6 & 3 & & 0.500 & 0.500 \\
\hline
\end{tabular}

(GenBank Accession No. X70182). As in man and mouse, two beta-enolase transcripts with distinct sequences in their $5^{\prime}$-UTR are present in pig muscle with a $142 \mathrm{bp}$ insert in the long form of pig beta enolase mRNA.

As an early marker of human myogenesis [6], ENO3 is responsible for over $90 \%$ of the enolase activity in adult human muscle and plays an important role in muscle diseases [4]. In our study, we used the real-time PCR technique to examine the tissue expression of both ENO3 transcripts and expression changes of these mRNAs during three important stages of skeletal muscle development in different pig breeds. This technique is useful to identify some functions of ENO3 during muscle development. A previous analysis of the relative expression of both spliced forms in developing and adult muscle did not show any stage-specific or tissue-specific pattern [12]. Our findings demonstrate that the expression of pig ENO3 transcript 2 is high in adult skeletal muscle and heart. The two spliced forms are expressed during the three postnatal stages of skeletal muscle development in Yorkshire pigs and the highest levels are observed in skeletal muscle at postnatal 1 day. In mouse, [1] have shown that the level of beta enolase is increased in newborn and adult muscle, and [8] and [9] have reported that it is also increased during foetal muscle development and during terminal differentiation of myoblasts, respectively. Hence, it is possible that beta enolase plays important roles during skeletal muscle development, including muscle differentiation. In addition, transcript 2 is relatively more abundant in skeletal muscle tissue and has a higher expression level in Western Yorkshire than in Chinese Meishan pigs. Thus, we propose that the ENO3 transcript 2 might play an important and different role in different breeds in terms of transcript level during muscle development.

As shown, the alternative splice site of the different transcripts is in the $3^{\prime}$ end of exon 1 . However, only one product is obtained after amplification with primer 
Table IV. Association analysis of the ENO3 polymorphism.

\begin{tabular}{lccccccc}
\hline Population & Genotype & Number & Fat (\%) & $\begin{array}{c}\text { Average } \\
\text { backfat } \\
\text { thickness (cm) }\end{array}$ & $\begin{array}{c}\text { Marbling of } \\
\text { m. longissimus } \\
\text { dorsi }\end{array}$ & $\begin{array}{c}\text { Marbling of } \\
\text { m. biceps femoris }\end{array}$ & $\begin{array}{c}\text { Intramuscular } \\
\text { fat (\%) }\end{array}$ \\
\hline 132 pigs $=$ 34 Yorkshire & $A A$ & 29 & $11.555 \pm 0.438^{\mathrm{ab}}$ & $1.761 \pm 0.134$ & $2.853 \pm 0.060^{\mathrm{a}}$ & $3.778 \pm 0.078^{\mathrm{a}}$ & $1.968 \pm 0.055^{\mathrm{A}}$ \\
37 Landrace & $A B$ & 59 & $11.379 \pm 0.315^{\mathrm{a}}$ & $1.646 \pm 0.046$ & $2.714 \pm 0.042^{\mathrm{ab}}$ & $3.609 \pm 0.054^{\mathrm{ab}}$ & $1.840 \pm 0.038^{\mathrm{A}}$ \\
35 Landrace $\times$ Yorkshire & $B B$ & 44 & $12.388 \pm 0.357^{\mathrm{b}}$ & $1.754 \pm 0.440$ & $2.686 \pm 0.047^{\mathrm{b}}$ & $3.554 \pm 0.061^{\mathrm{b}}$ & $1.680 \pm 0.043^{\mathrm{B}}$ \\
26 Yorkshire $\times$ Landrace & & & & & & & \\
140 F $_{2}$ Yorkshire $\times$ & $A A$ & 63 & $18.173 \pm 0.566^{\mathrm{a}}$ & $2.172 \pm 0.062^{\mathrm{a}}$ & $3.291 \pm 0.024^{\mathrm{a}}$ & $4.214 \pm 0.022^{\mathrm{A}}$ & $2.643 \pm 0.075^{\mathrm{A}}$ \\
Meishan offspring & $A B$ & 59 & $19.701 \pm 0.630^{\mathrm{ab}}$ & $2.213 \pm 0.069^{\mathrm{ab}}$ & $3.231 \pm 0.027^{\mathrm{ab}}$ & $4.096 \pm 0.024^{\mathrm{B}}$ & $2.226 \pm 0.083^{\mathrm{B}}$ \\
& $B B$ & 18 & $20.985 \pm 1.218^{\mathrm{b}}$ & $2.459 \pm 0.133^{\mathrm{b}}$ & $3.146 \pm 0.052^{\mathrm{b}}$ & $4.064 \pm 0.046^{\mathrm{B}}$ & $1.917 \pm 0.161^{\mathrm{B}}$ \\
\hline
\end{tabular}

Different letters indicate significantly different least square mean values, small letters $(\mathrm{a} / \mathrm{b})$ indicate $P<0.05$ and capital letters $(\mathrm{A} / \mathrm{B})$ indicate $P<0.01$. 
pair (EN1F, EN1R) and 5'-RACE primers and it contains the $3^{\prime}$ end of exon 1 and shares similar structural features with those of human ENO3 transcript variant 2. It is possible that the short form of mRNA has a high expression and the long form of mRNA possesses a specific structure leading to low expression. Furthermore, real-time PCR experiments revealed that the expression level of pig ENO3 transcript 1 is very low in skeletal muscle and all other tissue samples. Alternative splicing within the $5^{\prime}$-UTR is usually linked to alternative promoter usage. However, multiple beta-enolase mRNA forms arise from the same promoter, suggesting the possibility that regulated splicing may further control gene expression [7]. Variation in mRNA stability may result in different transcript levels [3]. Predictions of secondary structures indicate that the two transcripts of pig ENO3 gene could form different secondary structures. A more stable secondary structure may exist in the $5^{\prime}$ end of transcript 1 than in transcript 2 resulting in a low expression of transcript 1. In addition, it has been shown in man that transcripts containing the long and short leader sequences showed differences in the translational rate, suggesting a role for the ENO3 5'-UTR in the regulation of translation [12]. Thus, the 5'-untranslated sequences of pig ENO3 transcripts may regulate expression of both transcripts.

In this study, we have detected a new SNP (g.404delT) and carried out association studies. Allele frequencies are clearly different in Chinese indigenous breeds and in introduced commercial western breeds. Results of the association analysis with product traits in two different populations are nearly consistent. The polymorphism may be associated with variation in several carcass traits and meat quality traits of interest for pig breeding. Thus, we suggest that ENO3 might affect not only skeletal muscle growth during muscle development but also meat flavour and carcass quality. However, the number of animals analysed here is limited, which may affect the observed results. Further investigations in other pig populations are required to confirm the association study. In summary, our study shows that the porcine ENO3 gene may be an important candidate gene for meat quality and carcass traits in animal breeding and could be involved in muscle developmental mechanisms. These considerations are important for applications in animal breeding and provide a foundation for future research on the ENO3 gene.

\section{ACKNOWLEDGEMENTS}

We thank teachers and graduate students at Key Laboratory of Swine Genetics and Breeding, Ministry of Agriculture for managing and slaughtering research pig flocks. This study was supported financially by National High 
Technology Development project ('863' project: 2003AA243030) and the National Natural Science Foundation of China (Project No: 30700588).

\section{REFERENCES}

[1] Barbieri G., De Angelis L., Feo S., Cossu G., Giallongo A., Differential expression of muscle-specific enolase in embryonic and fetal myogenic cells during mouse development, Differentiation 45 (1990) 179-184.

[2] Chen S.H., Giblett E.R., Enolase human tissue distribution and evidence for three different loci, Ann. Hum. Genet. 39 (1976) 277-280.

[3] Cleveland D.W., Gene regulation through messenger RNA stability, Curr. Opin. Cell Biol. 1 (1989) 1148-1153.

[4] Comi G.P., Fortunato F., Lucchiari S., Bordoni A., Prelle A., Jann S., Keller A., Ciscato P., Galbiati S., Chiveri L., Torrente Y., Scarlato G., Bresolin N., Betaenolase deficiency, a new metabolic myopathy of distal glycolysis, Ann. Neurol. 50 (2001) 202-207.

[5] Feo S., Antona V., Barbieri G., Passantino R., Cali L., Giallongo A., Transcription of the human beta enolase gene (ENO-3) is regulated by an intronic muscle-specific enhancer that binds myocyte-specific enhancer factor 2 proteins and ubiquitous G-rich-box binding factors, Mol. Cell. Biol. 15 (1995) 5991-6002.

[6] Fougerousse F., Edom-Vovard F., Merkulova T., Ott M.O., Durand M., ButlerBrowne G., Keller A., The muscle-specific enolase is an early marker of human myogenesis, J. Muscle Res. Cell Motil. 22 (2001) 535-544.

[7] Giallongo A., Venturella S., Oliva D., Barvieri G., Rubino P., Feo S., Structure features of the human gene for muscle-specific enolase. Differential splicing in the $5^{\prime}$-untranslated sequence generates two forms of mRNA, Eur. J. Biochem. 214 (1993) 367-374.

[8] Keller A., Ott M.O., Lamande N., Lucas M., Gros F., Buckingham M., Lazar M., Activation of the gene encoding the glycolytic enzyme $b$ enolase during early myogenesis precedes an increased expression during fetal muscle development, Mech. Dev. 38 (1992) 41-54.

[9] Lamandé N., Brosset S., Lucas M., Keller A., Rouzeau J.D., Johnson T.R., Gros F., Ilan J., Lazar M., Transcriptional up-regulation of the mouse gene for the muscle-specific subunit of enolase during terminal differentiation of myogenic cells, Mol. Reprod. Dev. 41 (1995) 306-313.

[10] Larkin D.M., Kuznetsov S.B., Astakhova N.M., Zhdanova N.S., Use of PCR markers for mapping swine chromosome 12, Genetika 37 (2001) 358-364.

[11] Lucas M., Goblet C., Keller A., Lamandé N., Gros F., Whalen R.G., Lazar M., Modulation of embryonic and muscle-specific enolase gene products in the developing mouse hindlimb, Differentiation 51 (1992) 1-7.

[12] Oliva D., Venturella S., Passantino R., Feo S., Giallongo A., Conserved alternative splicing in the $5^{\prime}$-untranslated region of the muscle-specific enolase 
gene. Primary structure of mRNAs, expression and influence of secondary structure on the translation efficiency, Eur. J. Biochem. 232 (1995) 141-149.

[13] Peshavaria M., Day I., Molecular structure of the human muscle-specific enolase, Biochem J. 275 (1991) 427-433.

[14] Peterson C.A., Cho M., Rastinejad F., Blau H.M., Beta-enolase is a marker of human myoblast heterogeneity prior to differentiation, Dev. Biol. 151 (1992) 626-629.

[15] Sakimura K., Kushiya E., Ohshima-Ichimura Y., Mitsui H., Takahashi Y., Structure and expression of rat muscle-specific enolase gene, FEBS Lett. 277 (1990) 78-82.

[16] Wu J., Deng C.Y., Xiong Y.Z., Zhou D.H., Lei M.G., Zuo B., Li F.E., Wang J., cDNA cloning and polymorphism of the porcine carbonic anhydrase III (CA3) gene, Asian-Aust. J. Anim. Sci. 19 (2006) 324-328.

[17] Zuo B., Xiong Y.Z., Su Y.H., Deng C.Y., Zheng R., Jiang S.W., Mapping quantitative trait loci for meat quality on pig chromosome 3, 4 and 7, AsianAust. J. Anim. Sci. 16 (2003) 320-324.

[18] Zuo B., Xiong Y.Z., Deng C.Y., Su Y.H., Wang J., Lei M.G., Li F.E., Jiang S.W., Zheng R., cDNA cloning, genomic structure and polymorphism of the porcine FHL3 gene, Anim. Genet. 35 (2004) 220-233. 